\title{
Unexpected molecular mechanism of trimethylsilyl bromide elimination from 2-(trimethylsilyloxy)-3-bromo-3- methyl-isoxazolidines
}

\author{
Agnieszka Kącka-Zych ${ }^{1}$ (D) $\cdot$ Radomir Jasiński ${ }^{1}$
}

Received: 28 March 2019 / Accepted: 16 May 2019 / Published online: 31 May 2019

(c) The Author(s) 2019

\begin{abstract}
The molecular mechanism of elimination of the trimethylsilyl bromide (2) from 2-(trimethylsilyloxy)-3-bromo-3-methylisoxazolidines (1a-d) has been analyzed within the molecular electron density theory using density functional theory calculations at the M06-2X(PCM)/6-31+G(d) computational level. These elimination reactions take place via a two-step mechanism involving an intermediate. Bonding evolution theory analysis allows to set apart seven phases along the reaction path. Elimination of trimethylsilyl bromide starts with rupture of the $\mathrm{C} 1-\mathrm{Br} 2$ bond of 2-(trimethylsilyloxy)-3-bromo3-methyl-isoxazolidine (1a). Thereafter, we observed the formation of the N5-C1 double bond and the last step of this elimination is associated with formation of a new $\mathrm{Br} 2-\mathrm{Si} 3$ bond and breaking of the $\mathrm{Si} 3-\mathrm{O} 4$ bond.
\end{abstract}

Keywords Elimination · Trimethyl bromide · Isoxazolidines · Molecular electron density theory $\cdot$ Bonding evolution theory $\cdot$ Electron localization function

\section{Introduction}

Thermal elimination reactions are the most universal strategy for the stereoselective formation of unsaturated $\mathrm{C}=\mathrm{C}$ systems. For this purpose, processes of the decomposition of amine N-oxides (Cope reaction) [1, 2], ammonium hydroxides (Hoffman reaction) [1], xanthates (Chugaev reactions) $[1,3,4]$, alkyl carboxylates [5, 6], nitrocompounds $[7,8]$ as well as fluoroazoxy compounds $[9,10]$ can be applied. In the academic literature, it is generally assumed that these types of processes proceed according to the "concerted" mechanism via six- or five-membered, pericyclic transition state. However, the last discoveries in the field of molecular mechanisms of organic reactions undermine this insight [11]. For example, the comprehensive exploration in the framework of the MEDT study [12] shows without any doubts that the benzoic acid elimination from nitroalkyl esters should be treated as the one-step, multistage pseudocyclic reaction

Agnieszka Kącka-Zych

akacka@chemia.pk.edu.pl

1 Institute of Organic Chemistry and Technology, Cracow University of Technology, Warszawska 24, 31-155 Cracow, Poland
$[13,14]$. For similar conclusion, is provided in the quantum chemical studies of nitrous acid $[7,8]$ and fluorodiazo acid [10] eliminations. On the other hand, in thermal conditions, any ionic mechanism may not compete with the one-step mechanism. For this purpose, the presence of Lewis acids $[15,16]$ or cations of the ionic liquids [17] is necessary.

Recently, Ioffe and co-workers [18] described interesting strategy for the preparation of five-membered, internal nitronic esters which is based on the elimination of the trimethylsilyl bromide (2) from 2-(trimethylsilyloxy)-3-bromo3-methyl-isoxazolidine systems (1a-d).

This process is realized under relatively mild conditions and without intervention of toxic reagents. So, it may be attractive alternative for traditional protocol for preparation of five-membered, internal nitronic esters based on the transformations of mercuric nitroform salts [19-22]. Unfortunately, the molecular mechanism of the transformation described by Ioffe [18] is unknown. Therefore, we decide to shed light on the nature of the mentioned elimination. This can be better understand the factors, which may be determined scope of the applications of title reaction, and, in the consequence more optimal planning of organic syntheses if widely range of five-membered, internal nitronates.

In order to understand the energetics as well as molecular mechanistic aspects of the elimination, a MEDT study [12] 
of the title reaction was carried out at the M06-2X(PCM)/6$31+\mathrm{G}(\mathrm{d})$ computational level, in which a combination of: (i) a DFT study of molecular mechanism of elimination of trimethylsilyl bromide (2) from 2-(trimethylsilyloxy)3-bromo-3-methyl-isoxazolidines (1a-d) (Scheme 1), (ii) ELF topological analysis of 2-(trimethylsilyloxy)-3-bromo3-methyl-isoxazolidine (1a) and (iii) a BET analysis of the elimination reaction of trimethylsilyl bromide (2) from 1a, was employed. This approach, as we have proved, is effective tool for studying the molecular mechanism of various types of reactions [13-17].

\section{Computational details}

All calculations associated with the elimination of trimethylsilyl bromide (2) from 2-(trimethylsilyloxy)-3-bromo-3-methyl-isoxazolidines (1a-d) were performed using the Gaussian 16 package [23] in the Prometheus computer cluster of the CYFRONET regional computer centre in Cracow. The geometries of all reactants, transition state structures (TSs) and products of the reactions were fully optimized using the M06-2X functional [24] together with the 6-31+G(d) basis set. This computational level has already been successfully used for the exploration of a reaction involving several different nitrocompounds and others [25-27]. Critical points were characterized by frequency calculations. All reactants and products had positive Hessian eigenvalues. All TSs had only one negative eigenvalue in their diagonalized Hessian matrices, and their associated eigenvectors were confirmed to correspond to the motion along the reaction coordinate under consideration. TSs were located using the (QST2) algorithm. Intrinsic reaction coordinate (IRC) calculations [28] were performed in all cases to verify that the located TSs are connected to the corresponding minimum critical points associated with reactants, products and intermediates. The polarity of the reaction environment was simulated using a relatively simple self-consistent reaction field (SCRF) [29, 30] based on the polarizable continuum model (PCM) of Tomasi's group [31, 32]. The values of enthalpies, entropies and Gibbs free energies were calculated with the standard statistical thermodynamics at $25^{\circ} \mathrm{C}$ and 1 atm [33].

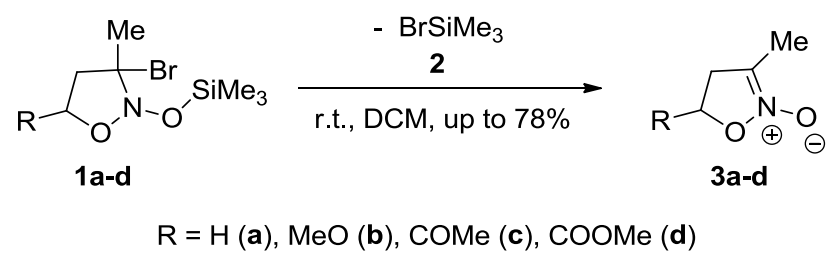

Scheme 1 General scheme of elimination trimethyl bromide (2) from 2-(trimethylsilyloxy)-3-bromo-3-methyl-isoxazolidines (1a-d)
The topological analyses of the electron localization function (ELF) were performed with the TopMod [34] program using the corresponding M06-2X/6-31+G(d) monodeterminantal wave functions. ELF calculations were computed over a grid spacing of 0.1 a.u. for each structure, and ELF localization domains were obtained for an ELF value of 0.75 . For the BET [35] studies, the corresponding reaction paths were followed by performing the topological analysis of the ELF for at least 76 nuclear configurations along the IRC paths.

\section{Results and discussion}

The MEDT study has been shared in three sections: In Sect. 3.1, the reaction profiles associated with the elimination of trimethylsilyl bromide (2) from 2-(trimethylsilyloxy)3-bromo-3-methyl-isoxazolidines (1a-d) are analyzed, in Sect. 3.2, the ELF analysis of 2-(trimethylsilyloxy)3-bromo-3-methyl-isoxazolidine (1a) is performed and in Sect. 3.3, a BET analysis of the elimination of trimethylsilyl bromide (2) from 2-(trimethylsilyloxy)-3-bromo-3-methylisoxazolidine (1a).

\subsection{Study of the reaction path associated with the elimination of trimethylsilyl bromide (2) from 2-(trimethylsilyloxy)-3-bromo-3-me- thyl-isoxazolidines (1a-d)}

From formal point of view, the most probable scenario of elimination of trimethylsilyl bromide (2) from 2-(trimethylsilyloxy)-3-bromo-3-methyl-isoxazolidine (1a) is a one-step mechanism (Scheme 2, path A), which may be realized via synchronical or non-synchronical transition state. However, ionic E1-type (path B) or E1cb-type (path C) mechanisms theoretically are also possible in some degrees. Therefore, all of these possibilities have been explored.

In our study, we started from the analysis of reaction profile of elimination from parent $\mathrm{N}$-oxide 1a. Unexpectedly, all attempts for optimization of the TS which may be connected with the transition state in the channel A were not successful. The DFT simulations show without any doubts that between valleys of starting molecule and products exist, not one, but three critical points, which can be connected with two transition states (TS1a and TS2a) and intermediate (IPa), respectively (Fig. 1).

The conversion of starting molecule leads in the first reaction stage to the energetic maximum one, which can be connected with the TS1a structure. This is accompanied with increasing Gibbs free energy about $7 \mathrm{kcal} / \mathrm{mol}$ and slight reduction of the entropy (Table 1). Within the TS1a, the $\mathrm{C} 1-\mathrm{Br} 2$ single bond is broken and the rehybridization on the $\mathrm{C} 1$ carbon atom is observed. In the consequence, the N2-C1 bond decreases to $1.32 \AA$. So, the localized transition state 
Scheme 2 Theoretically possible mechanisms for elimination of 2 from 2-(trimethylsilyloxy)3-bromo-3-methyl-isoxazolidines (1a)

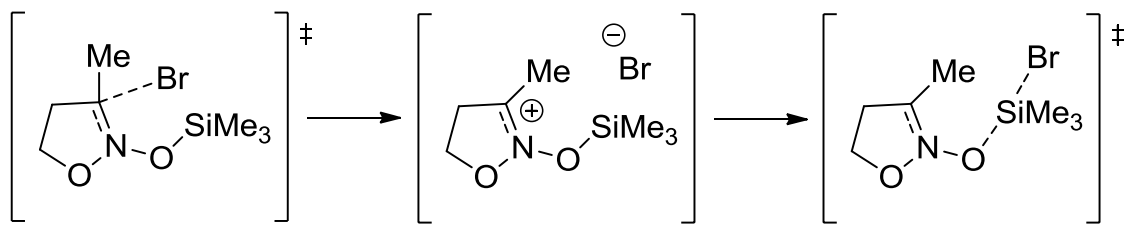

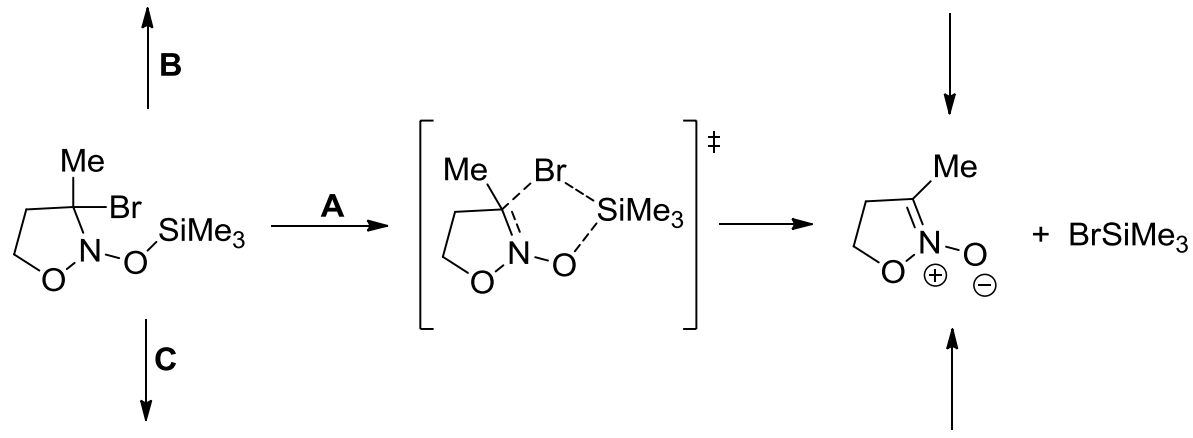<smiles>C[SiH3]ON1OCCC1(C)Br</smiles>

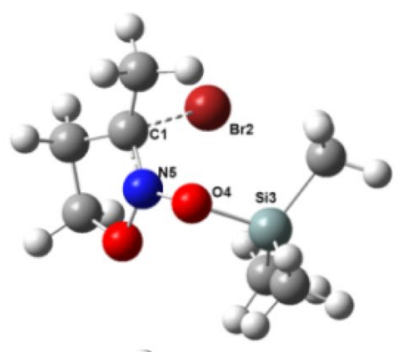

TS1a
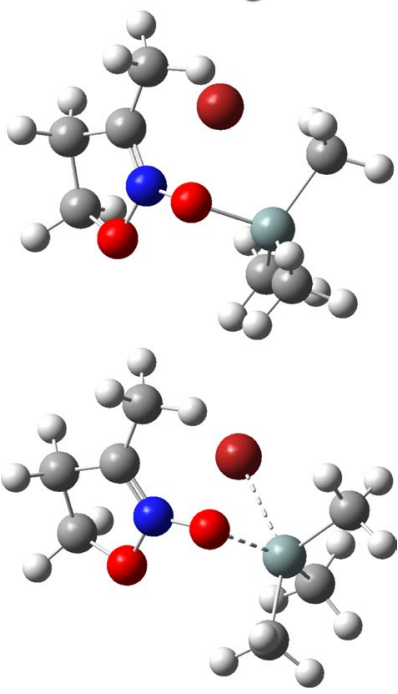

IPa

TS2a

Fig. 1 M06-2X/6-31+G(d) geometries of TSs and intermediate associated with the elimination of trimethylsilyl bromide (2) from 2-(trimethylsilyloxy)-3-bromo-3-methyl-isoxazolidine (1a) should be connected with the E1-type mechanism according to the channel $\mathbf{B}$ (Table 2).

Further conversion of the reaction system leads to the valley of the intermediate IPa. This intermediate is non-stable from thermodynamic point of view, because its Gibbs free energy is higher about $6 \mathrm{kcal} / \mathrm{mol}$ than in the case of the starting molecule. Within the IPa, the distance $\mathrm{C} 1-\mathrm{Br} 2$ is equal to $3 \AA$, whereas the N5-C1 connection exhibits nature of double bond ( $1.283 \AA$ ). The analysis of population of the Mulliken charges shows that this intermediate can be considered as the ionic pair. Its further conversion proceeds via second transition state TS2a. This requires increasing Gibbs free energy about $21.1 \mathrm{kcal} / \mathrm{mol}$. Within this transition state, the $\mathrm{Si} 3-\mathrm{O} 4$ single bond is broken. At the same time, the new $\mathrm{Br} 2-\mathrm{Si} 3$ single bond is formed. The IRC calculations connect this critical point with the valleys of IPa (from the first side) and products (from the second side) (Tables 1 and 2).

In the next step, the influence of the polarity solvent on the reaction course has been examined. For this purpose, we compared key geometrical and energetical parameters of critical structures optimized in the simulation in the presence of benzene ( $\omega=2.271)$, acetone $(\omega=20.493)$, nitromethane $(\omega=36.562)$ and water $(\omega=78.355)$ (Tables 1 and 2$)$. It was found that independently of solvent polarity, the transformation of $\mathbf{1 a}$ molecule into $\mathbf{2}+\mathbf{3 a}$ molecular system proceeds according to analogous mechanism. In all cases, three critical points between valleys of substrate and products have been identified. So, the nature of reaction profiles 
Table 1 Key energetical parameters of trimethylsilyl bromide (2) elimination from isoxazolidines (1a-d) according to M06-2X(PCM)/6$31+\mathrm{G}(\mathrm{d})$ calculations

\begin{tabular}{|c|c|c|c|c|c|}
\hline Solvent & $\frac{\text { Starting molecule }}{\mathrm{Me}}$ & Transition & $\Delta H(\mathrm{kcal} / \mathrm{mol})$ & $\Delta S(\mathrm{cal} / \mathrm{molK})$ & $\Delta G(\mathrm{kcal} / \mathrm{mol})$ \\
\hline \multirow[t]{4}{*}{ Benzene } & \multirow[t]{4}{*}{$\mathrm{H}$} & $1 \mathrm{a} \rightarrow$ TS1a & 6.0 & -atioa 3.8 & 7.1 \\
\hline & & $1 \mathrm{a} \rightarrow \mathrm{IPa}$ & 5.8 & -0.3 & 5.8 \\
\hline & & $1 \mathrm{a} \rightarrow$ TS2a & 20.3 & -2.6 & 21.1 \\
\hline & & $1 \mathrm{a} \rightarrow 2+3 \mathrm{a}$ & 12.5 & 44.7 & -0.9 \\
\hline \multirow[t]{4}{*}{ Acetone } & \multirow[t]{4}{*}{$\mathrm{H}$} & $1 \mathrm{a} \rightarrow$ TS1a & 7.6 & -0.4 & 7.7 \\
\hline & & $1 \mathrm{a} \rightarrow \mathrm{IPa}$ & 2.7 & 2.3 & 2.1 \\
\hline & & $1 \mathrm{a} \rightarrow$ TS2a & 20.5 & 1.2 & 20.1 \\
\hline & & $1 \mathrm{a} \rightarrow 2+3 \mathrm{a}$ & 11.3 & 41.1 & -0.9 \\
\hline \multirow[t]{4}{*}{ Nitromethane } & \multirow[t]{4}{*}{$\mathrm{H}$} & $1 \mathrm{a} \rightarrow$ TS1a & 7.7 & -1.4 & 8.1 \\
\hline & & $\mathbf{1 a} \rightarrow \mathrm{IPa}$ & 2.4 & 2.4 & 1.7 \\
\hline & & $1 \mathrm{a} \rightarrow$ TS2a & 20.3 & 1.9 & 19.8 \\
\hline & & $1 a \rightarrow 2+3 a$ & 11.2 & 40.8 & -1.0 \\
\hline \multirow[t]{4}{*}{ Water } & \multirow[t]{4}{*}{$\mathrm{H}$} & $1 \mathrm{a} \rightarrow$ TS1a & 7.7 & -2.0 & 8.3 \\
\hline & & $\mathbf{1 a} \rightarrow \mathrm{IPa}$ & 2.1 & 2.5 & 1.4 \\
\hline & & $1 \mathrm{a} \rightarrow$ TS2a & 20.2 & 2.6 & 19.5 \\
\hline & & $1 a \rightarrow 2+3 a$ & 11.0 & 42.0 & -1.5 \\
\hline \multirow[t]{12}{*}{ Benzene } & \multirow[t]{4}{*}{$\mathrm{MeO}$} & $1 b \rightarrow$ TS1b & 5.5 & -1.5 & 5.9 \\
\hline & & $\mathrm{Ib} \rightarrow \mathrm{IPb}$ & 5.7 & 6.8 & 3.7 \\
\hline & & $1 \mathrm{~b} \rightarrow \mathrm{TS} 2 \mathrm{~b}$ & 22.3 & -6.5 & 24.2 \\
\hline & & $1 b \rightarrow 2+3 b$ & 14.6 & 43.5 & 1.6 \\
\hline & \multirow[t]{4}{*}{$\mathrm{COMe}$} & $1 \mathrm{c} \rightarrow \mathrm{TS} 1 \mathrm{c}$ & 9.4 & -2.6 & 10.2 \\
\hline & & $1 \mathrm{c} \rightarrow \mathrm{IPc}$ & 9.7 & 3.5 & 8.6 \\
\hline & & $1 \mathrm{c} \rightarrow \mathrm{TS} 2 \mathrm{c}$ & 23.7 & -1.4 & 24.1 \\
\hline & & $1 c \rightarrow 2+3 c$ & 15.5 & 42.1 & 2.9 \\
\hline & \multirow[t]{4}{*}{ COOMe } & $1 d \rightarrow$ TS1d & 11.0 & -2.2 & 11.7 \\
\hline & & $1 d \rightarrow I P d$ & 11.6 & 2.3 & 10.9 \\
\hline & & $1 d \rightarrow$ TS2d & 25.6 & 0.0 & 25.6 \\
\hline & & $1 d \rightarrow 2+3 d$ & 16.9 & 47.2 & 2.9 \\
\hline
\end{tabular}

of considered processes is very similar. Their quantitative description is only different in some degrees. In particular, the Gibbs free energies of transition states in more polar solvent are slightly lower than in the benzene solution. On the other hand, the more polar solvents stabilize significantly the ionic intermediate IPa. In consequence, its Gibbs free energy in nitromethane is $1.3 \mathrm{kcal} / \mathrm{mol}$ lower than in the benzene solution.

Finally, other molecular systems (1b-d) including 2-(trimethylsilyloxy)-3-bromo-3-methyl-isoxazolidine moiety have been examined in similar type transformations (Tables 1,2). It was found that the nature of the substituent stimulates in some degrees the quantitative description of critical point on reaction profile. In particular, the presence of electron-donating substituents decreases the first activation barrier and increases thermodynamical stability of ionic pair. On the other hand, the presence of electron-withdrawing substituents increases the first activation barrier, with decreasing of the thermodynamical stability of ionic pair. It should be underlined, however, that independently of the nature of substitution of 5 positions of heterocyclic system, the elimination of the trimethylsilyl bromide proceeds according to the same, stepwise, E1-type mechanism. Thus, the proposed molecular mechanism can be treated 
Table 2 Key geometrical parameters of trimethylsilyl bromide (2) elimination from isoxazolidines (1a-d) according to M06-2X(PCM)/6$31+\mathrm{G}(\mathrm{d})$ calculations

\begin{tabular}{|c|c|c|c|c|c|c|c|}
\hline \multirow[t]{2}{*}{ Solvent } & \multirow{2}{*}{$\frac{\mathrm{R}_{\mathrm{O}-\mathrm{N}-\mathrm{O}^{-}}^{\text {Starting molecule }}}{\mathrm{Me}}$} & \multirow{2}{*}{$\begin{array}{l}\text { Critical } \\
\text { structure }\end{array}$} & \multicolumn{5}{|c|}{ Interatomic distances $[r(\AA)]$} \\
\hline & & & $\mathrm{C} 1-\mathrm{Br} 2$ & $\mathrm{Br} 2-\mathrm{Si} 3$ & $\mathrm{Si} 3-\mathrm{O} 4$ & O4-N5 & $\mathrm{N} 5-\mathrm{C} 1$ \\
\hline \multirow[t]{6}{*}{ Benzene } & \multirow[t]{6}{*}{$\mathrm{H}$} & 1a & 2.004 & 4.389 & 1.715 & 1.380 & 1.447 \\
\hline & & TS1a & 2.419 & 3.769 & 1.762 & 1.330 & 1.320 \\
\hline & & IPa & 2.921 & 3.972 & 1.787 & 1.318 & 1.283 \\
\hline & & TS2a & 3.185 & 2.568 & 2.056 & 1.280 & 1.282 \\
\hline & & 2 & & 2.261 & & & \\
\hline & & 3a & & & & 1.241 & 1.297 \\
\hline \multirow[t]{6}{*}{ Acetone } & \multirow[t]{6}{*}{$\mathrm{H}$} & 1a & 2.011 & 4.690 & 1.722 & 1.379 & 1.446 \\
\hline & & TS1a & 2.320 & 3.695 & 1.756 & 1.338 & 1.340 \\
\hline & & IPa & 3.087 & 4.116 & 1.787 & 1.318 & 1.281 \\
\hline & & TS2a & 3.242 & 2.646 & 1.984 & 1.290 & 1.282 \\
\hline & & 2 & & 2.276 & & & \\
\hline & & 3a & & & & 1.252 & 1.293 \\
\hline \multirow[t]{6}{*}{ Nitromethane } & \multirow[t]{6}{*}{$\mathrm{H}$} & $1 \mathbf{a}$ & 2.012 & 4.691 & 1.723 & 1.379 & 1.445 \\
\hline & & TS1a & 2.315 & 3.691 & 1.756 & 1.339 & 1.342 \\
\hline & & IPa & 3.095 & 4.125 & 1.787 & 1.318 & 1.281 \\
\hline & & TS2a & 3.248 & 2.649 & 1.981 & 1.290 & 1.282 \\
\hline & & 2 & & 2.277 & & & \\
\hline & & 3a & & & & 1.253 & 1.293 \\
\hline \multirow[t]{6}{*}{ Water } & \multirow[t]{6}{*}{$\mathrm{H}$} & 1a & 2.013 & 4.691 & 1.723 & 1.379 & 1.445 \\
\hline & & TS1a & 2.312 & 3.688 & 1.756 & 1.339 & 1.343 \\
\hline & & IPa & 3.101 & 4.130 & 1.787 & 1.318 & 1.281 \\
\hline & & TS2a & 3.251 & 2.654 & 1.979 & 1.291 & 1.282 \\
\hline & & 2 & & 2.278 & & & \\
\hline & & 3a & & & & 1.253 & 1.293 \\
\hline \multirow[t]{15}{*}{ Benzene } & \multirow[t]{5}{*}{$\mathrm{MeO}$} & $1 b$ & 2.003 & 4.313 & 1.716 & 1.379 & 1.451 \\
\hline & & TS1b & 2.586 & 3.811 & 1.772 & 1.324 & 1.302 \\
\hline & & $\mathbf{I P b}$ & 2.988 & 3.910 & 1.787 & 1.317 & 1.281 \\
\hline & & TS2b & 3.096 & 2.566 & 2.076 & 1.277 & 1.283 \\
\hline & & $3 \mathbf{b}$ & & & & 1.237 & 1.295 \\
\hline & \multirow[t]{5}{*}{$\mathrm{COMe}$} & $1 c$ & 2.000 & 4.250 & 1.715 & 1.379 & 1.451 \\
\hline & & TS1c & 2.642 & 3.879 & 1.778 & 1.321 & 1.296 \\
\hline & & IPc & 2.990 & 3.907 & 1.790 & 1.315 & 1.281 \\
\hline & & TS2c & 3.139 & 2.571 & 2.063 & 1.279 & 1.283 \\
\hline & & $3 c$ & & & & 1.239 & 1.296 \\
\hline & \multirow[t]{5}{*}{ COOMe } & $1 d$ & 1.992 & 4.699 & 1.721 & 1.375 & 1.451 \\
\hline & & TS1d & 2.699 & 3.927 & 1.783 & 1.319 & 1.291 \\
\hline & & IPd & 2.884 & 3.923 & 1.791 & 1.315 & 1.282 \\
\hline & & TS2d & 3.087 & 2.565 & 2.085 & 1.276 & 1.282 \\
\hline & & 3d & & & & 1.236 & 1.297 \\
\hline
\end{tabular}



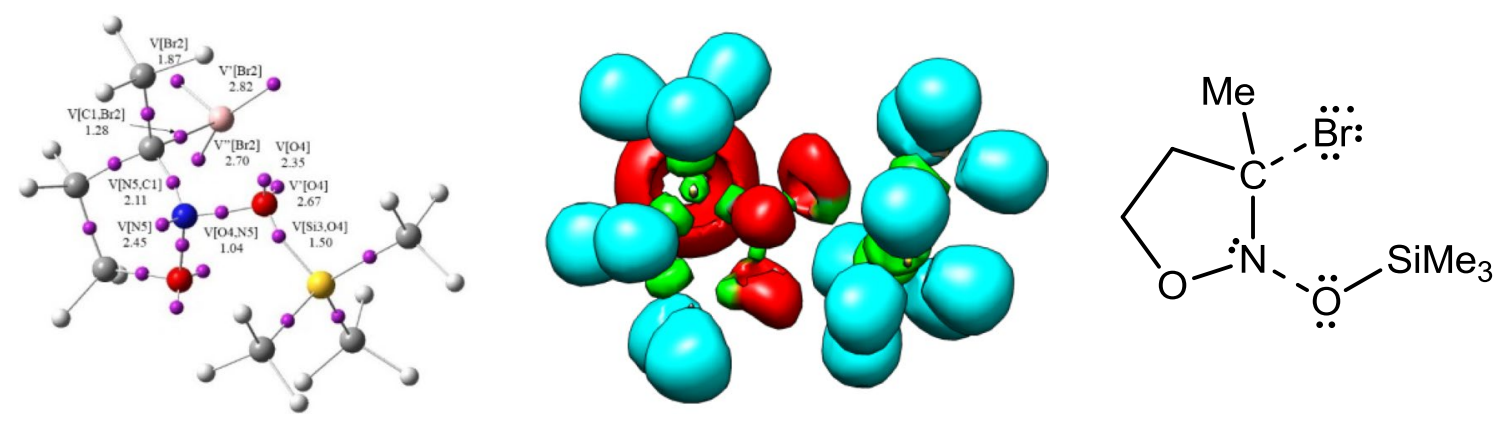

Fig. 2 Representation of ELF attractors together with valence basin population, ELF localization domains and the proposed Lewis structure of 1a

as general scheme for some range of 2-(trimethylsilyloxy)isoxazolidine systems.

\subsection{ELF topological analysis of 2-(trimethylsilyloxy)-3-bromo-3-methyl-isox- azolidine (1a)}

First, we decided to analyze the electronic structure of reactant. For this purpose, a topological analysis of the ELF of 2-(trimethylsilyloxy)-3-bromo-3-methyl-isoxazolidine (1a) was performed. The ELF attractors, including the valence basin populations, ELF localization domains and the proposed Lewis structure from the ELF topological analysis for 1a, are shown in Fig. 2. ELF topological analysis of 1a shows the presence of four disynaptic basins: V(Si3,O4), $\mathrm{V}(\mathrm{N} 5, \mathrm{C} 1), \mathrm{V}(\mathrm{C} 1, \mathrm{Br} 2)$ and $\mathrm{V}(\mathrm{O} 4, \mathrm{~N} 5)$ with electron populations of $1.50 \mathrm{e}, 2.11 \mathrm{e}, 1.28 \mathrm{e}$ and $1.04 \mathrm{e}$. We also find six monosynaptic basins: $\mathrm{V}(\mathrm{O} 4)$ and $\mathrm{V}^{\prime}(\mathrm{O} 4)$, with electron populations of 2.35 e and 2.67 e and $\mathrm{V}(\mathrm{Br} 2), \mathrm{V}^{\prime}(\mathrm{Br} 2)$ and $\mathrm{V}^{\prime \prime}(\mathrm{Br} 2)$ with total population of 7.39 e and $\mathrm{V}(\mathrm{N} 5)$ with electron population of $2.45 \mathrm{e}$.

According to the Lewis structures, V(N5) monosynaptic basin, integrating 2.45 e is associated with lone pair. It is worth noting that two disynaptic basins $\mathrm{V}(\mathrm{C} 1, \mathrm{Br} 2)$ and $\mathrm{V}(\mathrm{O} 4, \mathrm{~N} 5)$ with electron populations of $1.28 \mathrm{e}$ and $1.04 \mathrm{e}$ have low electron population and should be treated as partial single bond (Fig. 2).

\subsection{BET study of the elimina- tion of trimethylsilyl bromide (2) from 2-(trimethylsilyloxy)-3-bromo-3-me- thyl-isoxazolidine (1a)}

The BET study of the elimination of trimethylsilyl bromide (2) from 2-(trimethylsilyloxy)-3-bromo-3-methyl-isoxazolidine (1a) indicates that this reaction is topologically characterized by seven different phases. The population of the most meaningful valence basins of the selected points of the IRC is included in Table 3. The attractor positions of the ELF for the important points along the IRC are shown in Fig. 3, while the basin population changes along the reaction path are graphically depicted in Fig. 4.

Phase I, $3.79 \AA \leq \mathrm{d}(\mathrm{C} 1-\mathrm{Br} 2)<4.10 \AA ⿻$, $8.29 \AA \geq$ $\mathrm{d}(\mathrm{Br} 2-\mathrm{Si} 3)>6.98 \AA$ and $3.24 \AA \leq \mathrm{d}(\mathrm{Si} 3-\mathrm{O} 4)<3.28 \AA$ ,begins at the P1. This point is the interrupt of the IRC from TS toward the isolated 2-(trimethylsilyloxy)-3-bromo-3-methyl-isoxazolidine (1a).The ELF picture of $\mathbf{P 1}$ represents small changes in ELF valence basin electron populations of 1a. ELF analysis of $\mathbf{P 1}$ shows slight increase in the population of $\mathrm{V}(\mathrm{Si} 3, \mathrm{O} 4), \mathrm{V}(\mathrm{O} 4, \mathrm{~N} 5), \mathrm{V}(\mathrm{N} 5, \mathrm{C} 1)$ disynaptic basins. In other side, the population of $\mathrm{V}(\mathrm{C} 1, \mathrm{Br} 2)$ disynaptic basin progressively decreases.

Phase II, $4.10 \AA \leq \mathrm{d}(\mathrm{C} 1-\mathrm{Br} 2)<4.57 \AA, 6.98 \AA \leq$ $\mathrm{d}(\mathrm{Br} 2-\mathrm{Si} 3)<7.12 \AA$ and $3.28 \AA \leq \mathrm{d}(\mathrm{Si} 3-\mathrm{O} 4)<3.33 \AA$, starts at P2. At this point, described by fold $F$ catastrophe, the first noticeable topological change along the IRC occurs in this phase. In this phase, we observed the disappearance of the disynaptic basin $\mathrm{V}(\mathrm{C} 1, \mathrm{Br} 2)$. We also notice that a new $\mathrm{V}(\mathrm{C} 1)$ and $\mathrm{V}$ ', $(\mathrm{Br} 2)$ monosynaptic basins integrating $0.40 \mathrm{e}$ and 2.08 e are established at P2. This new V(C1) monosynaptic basin is associated with the pseudoradical center at the C1 carbon of the structure $\mathbf{P 2}$.

Phase III, $4.57 \AA \leq \mathrm{d}(\mathrm{C} 1-\mathrm{Br} 2)<5.14 \AA, 7.12 \AA$ $\leq \mathrm{d}(\mathrm{Br} 2-\mathrm{Si} 3)<7.28 \AA$ and $3.33 \AA \leq \mathrm{d}(\mathrm{Si} 3-\mathrm{O} 4)<3.37 \AA$, which begins at TS1a, the next significant topological change along the reaction path takes place. In this point, described by fold $F$ catastrophe, we observed the disappearance of a $\mathrm{V}(\mathrm{C} 1)$ monosynaptic basin, the disappearance of $\mathrm{V}(\mathrm{N} 5)$ monosynaptic basin achieved the smallest value $1.93 \mathrm{e}$, and the $\mathrm{V}(\mathrm{O} 4)$ monosynaptic basin split into two $\mathrm{V}(\mathrm{O} 4)$ and $\mathrm{V}$ '(O4) monosynaptic basins, integrating 2.23 e and $2.66 \mathrm{e}$. In this phase, there is a first transition state (TS1a) of the elimination of trimethylsilyl bromide (2) from 2-(trimethylsilyloxy)-3-bromo-3-methyl-isoxazolidine $(\mathbf{1 a}) ; \mathrm{d}(\mathrm{C} 1-\mathrm{Br} 2)=4.57 \AA, \mathrm{d}(\mathrm{Br} 2-\mathrm{Si} 3)=7.12 \AA$ and $\mathrm{d}(\mathrm{Si} 3-\mathrm{O} 4)=3.33 \AA$ (Table 3, Fig. 3). 
Table 3 ELF valence basin populations, distances of the breaking and forming bonds for the structures of the IRC, $\mathbf{1 a}-\mathbf{2}+\mathbf{3 a}$, defining the seven phases characterizing the molecular mechanism of the elimination of trimethylsilyl bromide (2) from 2-(trimethylsilyloxy)-3-bromo3-methyl-isoxazolidine (1a)

\begin{tabular}{|c|c|c|c|c|c|c|c|c|c|}
\hline $\begin{array}{l}\text { Structures } \\
\text { Catastrophes }\end{array}$ & 1a & P1 & $\begin{array}{l}\mathbf{P 2} \\
F\end{array}$ & $\begin{array}{l}\text { TS1a } \\
F\end{array}$ & $\begin{array}{l}\mathbf{P 3} \\
C^{\dagger}\end{array}$ & $\begin{array}{l}\text { IPa } \\
F\end{array}$ & $\begin{array}{l}\mathbf{P 4} \\
C\end{array}$ & $\begin{array}{l}\text { TS2a } \\
F\end{array}$ & $2+3 a$ \\
\hline Phases & & $I$ & & $I I$ & $I I I$ & $I V$ & $V$ & $V I$ & VII \\
\hline $\mathrm{d}(\mathrm{C} 1-\mathrm{Br} 2)$ & 3.786 & 3.880 & 4.097 & 4.571 & 5.139 & 5.520 & 5.895 & 6.018 & 6.337 \\
\hline $\mathrm{d}(\mathrm{Br} 2-\mathrm{Si} 3)$ & 8.293 & 6.797 & 6.981 & 7.122 & 7.283 & 7.706 & 5.471 & 4.853 & 4.273 \\
\hline d(Si3-O4) & 3.240 & 3.265 & 3.281 & 3.329 & 3.367 & 3.378 & 3.527 & 3.885 & 5.375 \\
\hline d(O4-N5) & 2.607 & 2.569 & 2.550 & 2.514 & 2.493 & 2.489 & 2.447 & 2.419 & 2.346 \\
\hline $\mathrm{d}(\mathrm{N} 5-\mathrm{C} 1)$ & 2.735 & 2.695 & 2.622 & 2.495 & 2.436 & 2.425 & 2.418 & 2.424 & 2.451 \\
\hline $\mathrm{V}(\mathrm{C} 1, \mathrm{Br} 2)$ & 1.28 & 1.09 & 0.47 & & & & & & \\
\hline $\mathrm{V}(\mathrm{C} 1)$ & & & 0.40 & & & & & & \\
\hline $\mathrm{V}(\mathrm{Br} 2)$ & 1.87 & 2.83 & 3,46 & 1.53 & 1.94 & 2.88 & 4.72 & 4.47 & 2.32 \\
\hline $\mathrm{V}^{\prime}(\mathrm{Br} 2)$ & 2.82 & 3.42 & 3.01 & 3.03 & 2.91 & 2.69 & 3.19 & 3.14 & 2.34 \\
\hline$V^{\prime \prime}(\mathrm{Br} 2)$ & 2.70 & 1.22 & 1.29 & 2.44 & 2.34 & 3.05 & & & 2.42 \\
\hline$V^{\prime \prime}(\mathrm{Br} 2)$ & & & 2.08 & 1.41 & 1.31 & & & & \\
\hline $\mathrm{V}(\mathrm{Br} 2, \mathrm{Si} 3)$ & & & & & & & 0.62 & 1.11 & 1.56 \\
\hline $\mathrm{V}(\mathrm{Si} 3, \mathrm{O} 4)$ & 1.50 & 1.54 & 1.57 & 1.49 & 1.48 & 1.43 & 1.36 & & \\
\hline $\mathrm{V}(\mathrm{O} 4)$ & 2.35 & 4.97 & 4.86 & 2.23 & 2.51 & 2.61 & 2.32 & 2.63 & 2.83 \\
\hline$V^{\prime}(\mathrm{O} 4)$ & 2.67 & & & 2.66 & 2.36 & 2.35 & 2.56 & 3.51 & 3.11 \\
\hline $\mathrm{V}(\mathrm{O} 4, \mathrm{~N} 5)$ & 1.04 & 1.09 & 1.11 & 1.12 & 1.18 & 1.24 & 1.32 & 1.37 & 1.58 \\
\hline $\mathrm{V}(\mathrm{N} 5)$ & 2.45 & 2.34 & 2.20 & 1.93 & & & & & \\
\hline $\mathrm{V}(\mathrm{N} 5, \mathrm{C} 1)$ & 2.11 & 2.22 & 2.37 & 2.76 & 2.33 & 2.13 & 2.17 & 2.12 & 2.16 \\
\hline$V^{\prime}(\mathrm{N} 5, \mathrm{C} 1)$ & & & & & 2.14 & 2.27 & 2.11 & 2.14 & 2.23 \\
\hline
\end{tabular}

Distances are given in angstroms $\AA$ and electron populations in average number of electrons, e

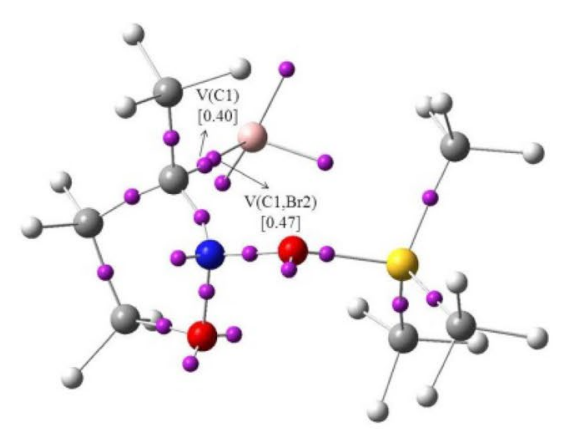

P2

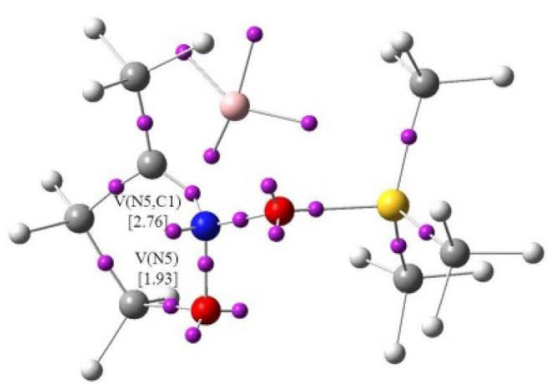

TS1a

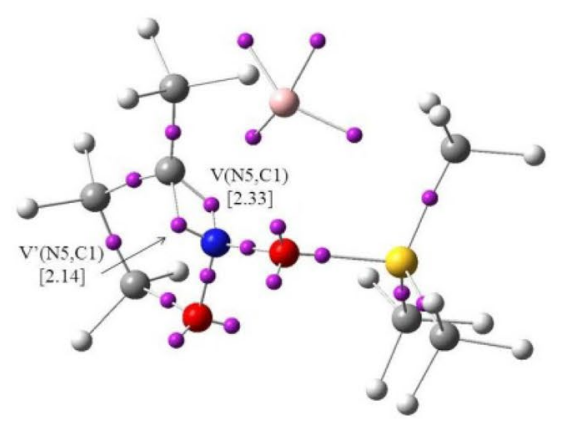

P3
Fig. 3 ELF attractor positions for the most relevant points along the IRC associated with the rupture of $\mathrm{C} 1-\mathrm{Br} 2$ bond and formation of double bond between $\mathrm{N} 5$ and $\mathrm{C} 1$ atoms during the elimination of

Phase IV, $5.14 \AA \leq \mathrm{d}(\mathrm{C} 1-\mathrm{Br} 2)<5.52 \AA, 7.28 \AA \leq$ $\mathrm{d}(\mathrm{Br} 2-\mathrm{Si} 3)<7.71 \AA$ and $3.37 \AA \leq \mathrm{d}(\mathrm{Si} 3-\mathrm{O} 4)<3.38 \AA$, starts at $\mathbf{P 3}$ and is featured by cusp $C^{\dagger}$ catastrophe. In this phase, the next most important topological change along the reaction path takes place; the $\mathrm{V}(\mathrm{N} 5)$ monosynaptic basin disappears, and a new $\mathrm{V}^{\prime}(\mathrm{N} 5, \mathrm{C} 1)$ disynaptic basin integrating $2.14 \mathrm{e}$ is formed. This new V' $(\mathrm{N} 5, \mathrm{C} 1)$ disynaptic basin is associated with the formation of a double bond between $\mathrm{N} 5$ and $\mathrm{C} 1$ atoms. trimethylsilyl bromide (2) from 2-(trimethylsilyloxy)-3-bromo-3-methyl-isoxazolidine (1a)

At IPa, $5.52 \AA \leq \mathrm{d}(\mathrm{C} 1-\mathrm{Br} 2)<5.90 \AA, 7.71 \AA \geq$ $\mathrm{d}(\mathrm{Br} 2-\mathrm{Si} 3)>5.47 \AA$ and $3.38 \AA \leq \mathrm{d}(\mathrm{Si} 3-\mathrm{O} 4)<3.53 \AA$, commences the Phase $V$, which is described by fold $F$ catastrophe. At this phase, the $\mathrm{V}^{\prime \prime},(\mathrm{Br} 2)$ monosynaptic basin disappears. We find in this phase an intermediate (IPa) of the studied reactions; $\mathrm{d}(\mathrm{C} 1-\mathrm{Br} 2)=5.52 \AA, \mathrm{d}(\mathrm{Br} 2-\mathrm{Si} 3)=7.71 \AA$ and $\mathrm{d}(\mathrm{Si} 3-\mathrm{O} 4)=3.38 \AA$ (Table 3, Fig. 3).

Phase VI, $5.90 \AA \leq \mathrm{d}(\mathrm{C} 1-\mathrm{Br} 2)<6.02 \AA, 5.47 \AA \geq$ $\mathrm{d}(\mathrm{Br} 2-\mathrm{Si} 3)>4.85 \AA$ and $3.53 \AA \leq \mathrm{d}(\mathrm{Si} 3-\mathrm{O} 4)<3.89 \AA$, starts 

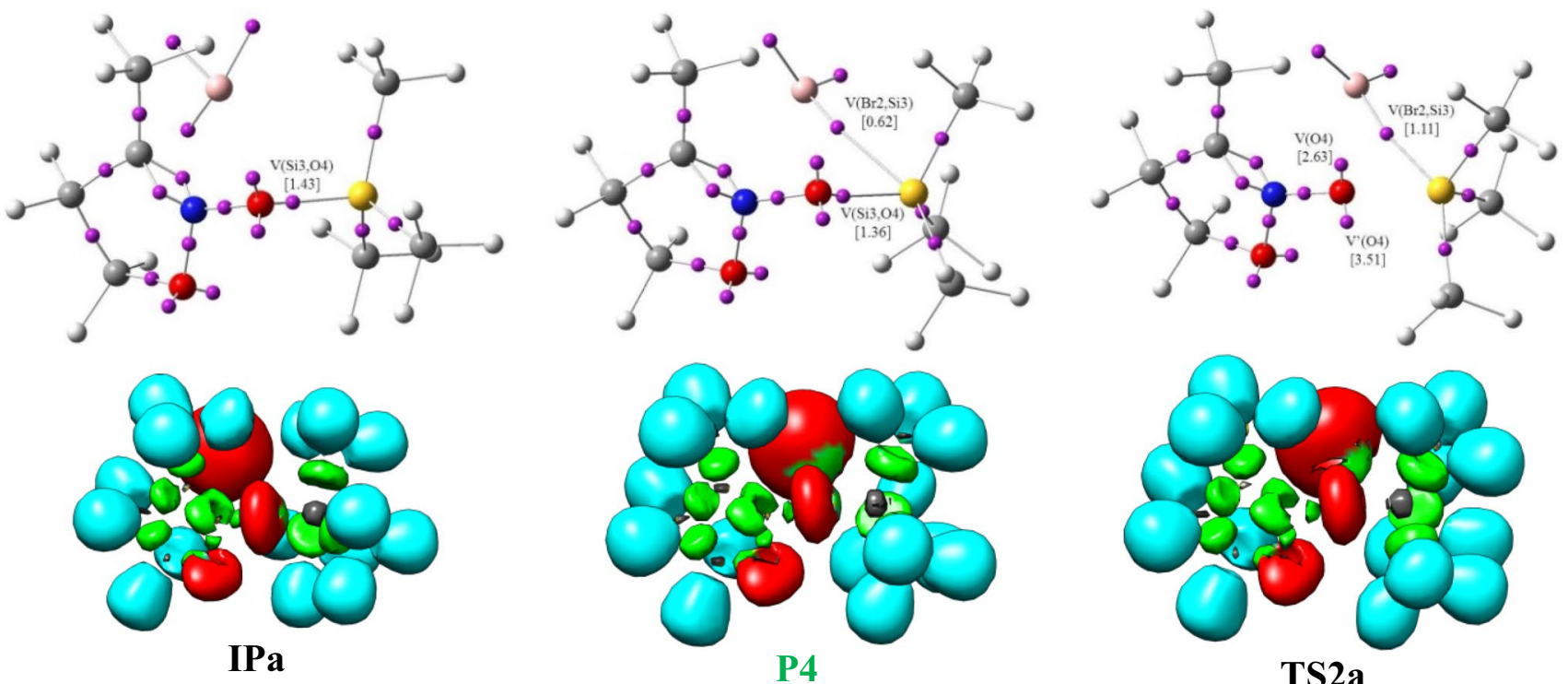

Fig. 4 ELF attractor positions and basins for the most relevant points along the IRC associated with the formation of the Br2-Si3 bond and rupture of the $\mathrm{Si} 3-\mathrm{O} 4$ bond during the elimination of trimethylsilyl bromide (2) from 2-(trimethylsilyloxy)-3-bromo-3-methyl-isoxazolidine (1a)

at $\mathbf{P 4}$. At this point, described by cusp $C$ catastrophe, a new $\mathrm{V}(\mathrm{Br} 2, \mathrm{Si} 3)$ disynaptic basin appears with the population $0.62 \mathrm{e}$ as a consequence of the disappearance of a $\mathrm{V}^{\prime \prime}(\mathrm{Br} 2)$ monosynaptic basin integrating $3.05 \mathrm{e}$.

Finally, the last Phase VII, $6.02 \AA \leq \mathrm{d}(\mathrm{C} 1-\mathrm{Br} 2)<6.34 \AA$, $4.85 \AA \geq \mathrm{d}(\mathrm{Br} 2-\mathrm{Si} 3)>4.27 \AA$ and $3.89 \AA \leq \mathrm{d}(\mathrm{Si} 3-\mathrm{O} 4)$ $<5.38 \AA$, begins at TS2a, which is described by fold $F$ catastrophe. At this point, the next significant topological change takes place; a $\mathrm{V}(\mathrm{Si} 3, \mathrm{O} 4)$ disynaptic basin integrating 1.36e disappears. This phase begins at second transition state (TS2a) of the analyzed reaction; $\mathrm{d}(\mathrm{C} 1-\mathrm{Br} 2)=6.02 \AA$, $\mathrm{d}(\mathrm{Br} 2-\mathrm{Si} 3)=4.85 \AA$ and $\mathrm{d}(\mathrm{Si} 3-\mathrm{O} 4)=3.89 \AA$ (Table 3, Fig. 4). In products of reaction $\mathbf{2}+\mathbf{3 a}$, we also observed the formation of $\mathrm{V}$ ' $(\mathrm{Br} 2)$ monosynaptic basin integrating 2.42e.

From the BET analysis of this elimination of trimethylsilyl bromide (2) from 2-(trimethylsilyloxy)-3-bromo-3-methyl-isoxazolidine (1a), some interesting conclusions can be drawn: (i) BET analysis allows to distinguish seven phases along the reaction path which have been grouped into four Groups A-D (Table 4); (ii) Group A, which includes Phases I-II, is associated with the rupture of the $\mathrm{C} 1-\mathrm{Br} 2$ bond of 2-(trimethylsilyloxy)-3-bromo-3-methyl-isoxazolidine (1a); (iii) the rupture of this bond leads to formation of two $\mathrm{C} 1$ and $\mathrm{Br} 2$ pseudoradical centers; (iv) Group $\mathrm{B}$, containing Phases III-V, is mainly associated with the formation of the N5-C1 double bond; (v) Group C, including Phase VI, is related to formation of a new $\mathrm{Br} 2-\mathrm{Si} 3$ bond. It is worth noting that when the $\mathrm{Br} 2-\mathrm{Si} 3$ bond is formed, the $\mathrm{Si} 3-\mathrm{O} 4$ bond is not broken yet. (vi) The breaking of the $\mathrm{Si3}-\mathrm{O} 4$ bond takes place in the last Phase VII, which is included in the last Group D. In this group, we also observed the formation of the products of reaction $\mathbf{2}$ and $\mathbf{3 a}$.

\section{Conclusions}

The reaction of elimination of trimethylsilyl bromide (2) from 2-(trimethylsilyloxy)-3-bromo-3-methyl-isoxazolidines (1a-d) has been studied using DFT methods at the M06$2 \mathrm{X}(\mathrm{PCM}) / 6-31+\mathrm{G}(\mathrm{d})$ computational level through the combination of the exploration and characterization of the reaction profiles associated with the elimination of trimethylsilyl bromide (2) from 2-(trimethylsilyloxy)-3-bromo-3-methylisoxazolidines (1a-d) and analysis based on MEDT theory. The title elimination reactions of trimethyl bromide (2) from 2-(trimethylsilyloxy)-3-bromo-3-methyl-isoxazolidines (1a-d) become via a E1-type two-step mechanism. BET analysis of the elimination of $\mathbf{2}$ from $\mathbf{1 a}$ indicates that this reaction begins with rupture of the $\mathrm{C} 1-\mathrm{Br} 2$ bond. Successively, we observed the formation of N5-C1 double bond and next the bond between atoms $\mathrm{Br} 2$ and $\mathrm{Si} 3$. And the last stage of the reaction is the rupture of the $\mathrm{Si} 3-\mathrm{O} 4$ bond. 
Table 4 Sequential bonding changes takes place the elimination of trimethylsilyl bromide (2) from 2-(trimethylsilyloxy)-3-bromo-3-methyl-isoxazolidine (1a), showing the equivalence between the topological characterization of the different phases and the chemical processes occurring among them. Distances are given in angstroms, $\AA$<smiles>C[AsH]ON1OCCC1(C)Br</smiles>

P1<smiles>CC([Hg])ON1OCCC1C</smiles>

P3<smiles>CCCC</smiles><smiles>CC1=C([Hg])CO[N+]1O[SiH3]</smiles>

IPa<smiles>CC#CC1CC(C)=[N+](O[SiH3])O1</smiles>

TS1a

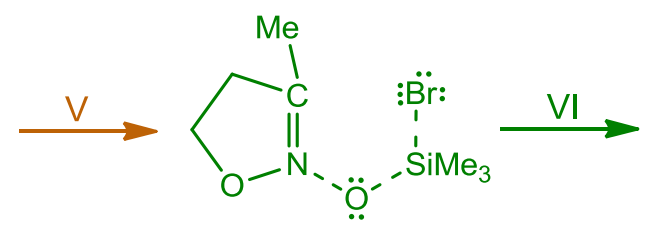

P4

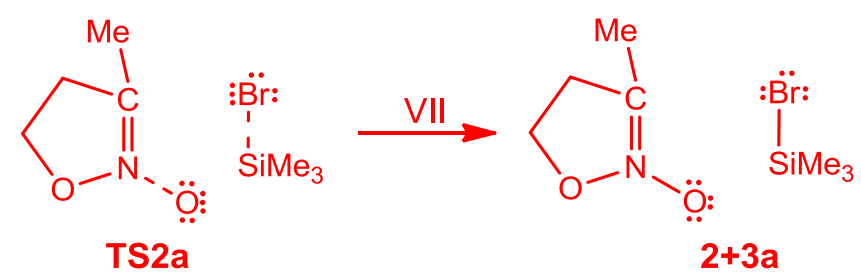

\begin{tabular}{|c|c|c|c|c|}
\hline Group & Phases & $\begin{array}{l}d_{1}(\mathrm{C} 1-\mathrm{Br} 2) \\
d_{2}(\mathrm{Br} 2-\mathrm{Si} 3) \\
d_{3}(\mathrm{Si} 3-\mathrm{O} 4)\end{array}$ & $\begin{array}{l}\text { Topological } \\
\text { characterization }\end{array}$ & Chemical process \\
\hline A & I-II & $\begin{array}{l}3.88 \leq d_{1}<4.57 \\
6.80 \leq d_{2}<7.12 \\
3.27 \leq d_{3}<3.33\end{array}$ & $\begin{array}{l}\text { Disappearance of the } \mathrm{V}(\mathrm{C} 1, \mathrm{Br} 2) \text { disynaptic basin and formation of } \\
\mathrm{V}(\mathrm{C} 1) \text { and } \mathrm{V}^{\prime},{ }^{\prime}(\mathrm{Br} 2) \text { monosynaptic basins }\end{array}$ & Rupture of the $\mathrm{C} 1-\mathrm{Br} 2$ bond \\
\hline B & III-V & $\begin{array}{l}4.57 \leq d_{1}<5.90 \\
7.12 \leq d_{2}<5.47 \\
3.33 \leq d_{3}<3.53\end{array}$ & $\begin{array}{l}\text { Formation of the } \mathrm{V}^{\prime}(\mathrm{N} 5, \mathrm{C} 1) \text { disynaptic basin and disappearance of } \\
\mathrm{V}(\mathrm{N} 5) \text { monosynaptic basin }\end{array}$ & Formation of the N5-C1 double bond \\
\hline $\mathrm{C}$ & VI & $\begin{array}{l}5.90 \leq d_{1}<6.02 \\
7.47 \geq d_{2}>4.85 \\
3.53 \leq d_{3}<3.89\end{array}$ & $\begin{array}{l}\text { Formation of the } \mathrm{V}(\mathrm{Br} 2, \mathrm{Si} 3) \\
\text { disynaptic basin }\end{array}$ & Formation of the $\mathrm{Br} 2-\mathrm{Si} 3$ bond \\
\hline $\mathrm{D}$ & VII & $\begin{array}{l}6.02 \leq d_{1}<6.34 \\
4.85 \geq d_{2}>4.27 \\
3.89 \leq d_{3}<5.38\end{array}$ & $\begin{array}{l}\text { Disappearance of the } \mathrm{V}(\mathrm{Si} 3, \mathrm{O} 4) \text { disynaptic basin and formation of the } \\
\mathrm{V} \text { ' }(\mathrm{Br} 2) \text { monosynaptic basin in product of reaction }\end{array}$ & Rupture of the $\mathrm{Si} 3-\mathrm{O} 4$ bond \\
\hline
\end{tabular}

Acknowledgements This research was supported in part by PL-Grid Infrastructure and financial support from the Polish State Committee (Grant No. C-2/493/2018/DS-M) is gratefully acknowledged.

Open Access This article is distributed under the terms of the Creative Commons Attribution 4.0 International License (http://creativecommons.org/licenses/by/4.0/), which permits unrestricted use, distribution, and reproduction in any medium, provided you give appropriate credit to the original author(s) and the source, provide a link to the Creative Commons license, and indicate if changes were made.

\section{References}

1. DePuy CH, King RW (1960) Pyrolytic Cis Eliminations. Chem Rev 60:431-457

2. Gruffin RJ, Henderson A, Curtin NJ, Echalier A, Endicott JA, Hardcastle IR, Newell DR, Noble MEM, Wang LZ, Golding BT (2006) Searching for cyclin-dependent kinase inhibitors using a new variant of the cope elimination. J Am Chem Soc 128:6012-6013

3. Tschugaeff L (1900) Ueber das Thujen, ein neues bicyclisches Terpen. Berichte 33:31183126 
4. Meulemans TM, Stork GA, Macaev FZ, Jansen BJM, de Groot A (1999) Total synthesis of dihydroclerodin from (R)-(-)-Carvone. J Org Chem 64:9178-9188

5. Notario R, Quijano J, Sanchez C, Velez E (2005) Theoretical study of the mechanism of thermal decomposition of carbonate esters in the gas phase. J Phys Org Chem 18:134-141

6. Jasiński R, Kącka A (2015) A polar nature of benzoic acids extrusion from nitroalkyl benzoates: DFT mechanistic study. J Mol Model 21:59-65

7. Łapczuk-Krygier A, Jaśkowska J, Jasiński R (2018) The influence of Lewis acid catalyst on the kinetic and molecular mechanism of nitrous acid extrusion from 3-phenyl-5-nitro-2-isoxazoline: DFT computational study. Chem Het Comp 54:1172-1174

8. Jasiński R (2015) A new mechanistic insight on beta-lactam systems formation from 5-nitroisoxazolidines. RSC Adv 5:50070-50072

9. Grebennikov VN, Manelis GB, Nazin GM, Studnev YN, Fokin AV (1984) Thermal decomposition of N-fluoroazoxy derivatives. Russ Chem Bull 33:1573-1575

10. Jasiński R (2014) Molecular mechanism of thermal decomposition of fluoronitroazoxy compounds: DFT computational study. J Fluor Chem 160:29-33

11. Domingo LR, Ríos-Gutiérrez M, Silvi B, Pérez P (2018) The mysticism of pericyclic reactions: a contemporary rationalisation of organic reactivity based on electron density analysis. Eur J Org Chem 2018:1107-1120

12. Domingo LR (2016) Molecular electron density theory: a modern view of reactivity in organic chemistry. Molecules 21:1319-1333

13. Kącka-Zych A, Domingo LR, Ríos-Gutiérrez M, Jasiński J (2017) Understanding the mechanism of the decomposition reaction of nitroethyl benzoate through the molecular electron density theory. Theor Chem Acc 136:129-138

14. Kącka A, Jasiński R (2016) A DFT mechanistic study of thermal decomposition reactions of nitroethyl carboxylates: undermine of pericyclic insight. Heteroatom Chem 27:279-289

15. Kącka-Zych A, Domingo LR, Jasiński R (2018) Does a fluorinated Lewis acid catalyst change the molecular mechanism of the decomposition process of nitroethyl carboxylates? Res Chem Int 44:325-337

16. Kącka-Zych A, Ríos-Gutiérrez M, Domingo LR (2019) A molecular electron density theory study of the Lewis acid catalyzed decomposition reaction of nitroethyl benzoate using aluminium derivatives. J Phys Org Chem e3938:1-12

17. Kącka A, Jasiński R (2017) A dramatic change of kinetic conditions and molecular mechanism of decomposition processes of nitroalkyl carboxylates catalyzed by ethylammonium cations. Comput Theor Chem 1104:37-42

18. Kunetsky AR, Dilman AD, Ioffe SL, Struchkova MI, Strelenko YA, Tartakovsky VA (2003) New approach for the synthesis of isoxazoline-N-oxides. Org Lett 5:4907-4909

19. Tartakovskii VA, Novikov SS, Godovikova TI (1961) Synthesis of organomercury nitro compounds. Russ Chem Bull 10:963-968

20. Tartakovskii VA, Savost'yanova IA, Gribov BG, Novikov SS (1963) Synthesis of $\gamma$-mercuridinitrohydrocarbons. Russ Chem Bull 12:1204-1205

21. Tartakovski VA, Gribov BG, Novikov SS (1965) Synthesis of $\gamma$-bromo dinitro compounds. Russ Chem Bull 14:1034-1035

22. Tartakovskii VA, Gribov BG, Sovost'yanova IA, Novikov SS (1965) Intramolecular O-alkylation of gem-dinitro compounds. Russ Chem Bull 14:1602-1605

23. Frisch MJ, Trucks GW, Schlegel HB, Scuseria GE, Robb MA, Cheeseman JR, Montgomery JA, Vreven TJ, Kudin KN, Burant JC, Millam JM, Iyengar SS, Tomasi J, Barone V, Mennucci B,
Cossi M, Scalmani G, Rega N, Petersson GA, Nakatsuji H, Hada M, Ehara M, Toyota K, Fukuda R, Hasegawa J, Ishida M, Nakajima Y, Honda O, Kitao O, Nakai H, Klene M, Li X, Knox JE, Hratchian HP, Cross JB, Adamo C, Jaramillo J, Gomperts R, Stratmann RE, Yazyev O, Austin AJ, Cammi R, Pomelli C, Ochterski JW, Ayala PY, Morokuma K, Voth GA, Salvador P, Dannenberg JJ, Zakrzewski VG, Dapprich S, Daniels AD, Strain MC, Farkas MC, Malick DK, Rabuck AD, Raghavachari K, Foresman JB, Ortiz JV, Cui Q, Baboul AG, Clifford S, Cioslowski J, Stefanov BB, Liu G, Liashenko A, Piskorz P, Komaromi I, Martin RL, Fox DJ, Keith T, Al-Laham MA, Peng CY, Nanayakkara A, Challacombe M, Gill PMW, Johnson B, Chen W, Wong MW, Gonzalez C, Pople JA (2016) Gaussian 16 rev A.1 Gaussian Inc Wallingford CT

24. Zhao Y, Schultz NE, Truhlar DG (2016) Design of density functionals by combining the method of constraint satisfaction with parametrization for thermochemistry, thermochemical kinetics, and noncovalent interactions. J Chem Theory Comput 2:364-382

25. Rhyman L, Ramasami P, Joule JA, Saez JA, Domingo LR (2013) Understanding the formation of $[3+2]$ and $[2+4]$ cycloadducts in the Lewis acid catalysed reaction between methyl glyoxylate oxime and cyclopentadiene: a theoretical study. RSC Adv 3:447-457

26. Rayenne D, Ouassila AY, Djameleddine K (2015) DFT-ONIOM study of the dopamine- $\beta$-CD complex: NBO and AIM analysis. Canad J Chem 93:1115-1121

27. Qiao Y, Chen X, Wei D, Chang J (2016) Insights into the competing mechanisms and origin of enantioselectivity for N-heterocyclic carbene-catalyzed reaction of aldehyde with enamide. Sci Rep 6:38200-38219

28. Fukui K (1970) Formulation of the reaction coordinate. J Phys Chem 74:4161-4163

29. Tapia O (1992) Solvent effect theories: quantum and classical formalisms and their applications in chemistry and biochemistry. J Math Chem 10:139-181

30. Tomasi J, Persico M (1994) Molecular interactions in solution: an overview of methods based on continuous distributions of the solvent. Chem Rev 94:2027-2094

31. Cances MT, Mennunci V, Tomasi J (1997) A new integral equation formalism for the polarizable continuum model: theoretical background and applications to isotropic and anisotropic dielectrics. J Chem Phys 107:3032-3041

32. Cossi M, Barone V, Cammi R, Tomasi J (1996) Ab initio study of solvated molecules: a new implementation of the polarizable continuum model. Chem Phys Lett 255:327-335

33. Berski S, Andres J, Silvi B, Domingo LR (2003) The joint use of catastrophe theory and electron localization function to characterize molecular mechanisms. A density functional study of the Diels-Alder reaction between Ethylene and 1,3-butadiene. J Phys Chem 107:6014-6024

34. Noury S, Krokidis K, Fuster F, Silvi B (1999) Computational tools for the electron localization function topological analysis. Comput Chem 23:597-604

35. Krokidis X, Noury S, Silvi B (1997) Characterization of elementary chemical processes by catastrophe theory. Theory J Phys Chem A 101:7277-7282

Publisher's Note Springer Nature remains neutral with regard to jurisdictional claims in published maps and institutional affiliations. 